\title{
A comparative study of sorption of chromium (III) onto chitin and chitosan
}

\author{
Pooja Singh $\cdot$ R. Nagendran
}

Received: 30 June 2013/Accepted: 1 July 2014/Published online: 25 July 2014

(C) The Author(s) 2014. This article is published with open access at Springerlink.com

\begin{abstract}
Heavy metals have always been the most hazardous components in the wastewater of industries like electroplating, automobiles, mining facilities and fertilizer manufacturers. Treatment of heavy metal laden wastewater requires expensive operational and maintenance systems. Food processing industries create a huge amount of shell waste which is sold to poultry farms in powdered form but the quantity thus used is still not comparable to the left over waste. The shell contains chitin which acts as an adsorbent for the heavy metals and can be used to treat heavy metal wastewater. The paper presents a study on the use of chitin and its processed product, chitosan, to remove chromium. Shake flask experiment was conducted to compare the adsorptive capacity of chitin and chitosan for chromium removal from simulated solution and isotherm studies were carried out. The studies showed that the chitosan was a better adsorbent than chitin. Both chitin and chitosan gave best adsorption results at $\mathrm{pH}$ 3. Chitin exhibited maximum chromium removal of $49.98 \%$ in 20 min, whereas chitosan showed $50 \%$ removal efficiency at a contact time of $20 \mathrm{~min}$ showing higher adsorptive capacity for chromium than chitin. The Langmiur and Freundlich isotherm studies showed very good adsorption capacity and monolayer interaction according to the regression coefficient 0.973 for chitosan and 0.915 for
\end{abstract}

P. Singh $(\bowtie)$

Centre for Environmental Studies, Anna University, Chennai 600025, India

e-mail: pooja_singhind@yahoo.co.in

R. Nagendran

National Green Tribunal, Southern zone, TNPCB Building,

Arumbakkam, Chennai 600106, India

e-mail: rnagendran@gmail.com chitin. The regression coefficient for Freundlich isotherm was 0.894 and 0.831 for chitosan and chitin, respectively.

Keywords Wastewater - Adsorption · Chromium - Chitin · Chitosan

\section{Introduction}

Heavy metals are essential for various biochemical processes but beyond a level they are known to be detrimental to life forms owing to their toxicity, persistent nature and tendency to bioaccumulate (Igwe and Abia 2006). Chromium is one such heavy metal used in electroplating, mining, automobiles, etc., making the effluent generated in these industries extremely harmful if not treated and disposed properly. Though required in trace amounts for biological functions, excess chromium is reported to cause health-related problems like rashes, ulcers, respiratory disorders, alteration in genetic material, cancer (Banerjee et al. 2010) and weakening of immune system (Shrivastava et al. 2002). In aqueous solution Chromium exists in two oxidation states, $\mathrm{Cr}^{3+}$ and $\mathrm{Cr}^{6+}$ (Mukherjee et al. 2013). Out of the two states $\mathrm{Cr}^{6+}$ is more toxic than the other but some strong oxidants can oxidize $\mathrm{Cr}^{3+}$ to $\mathrm{Cr}^{6+}$ (Zuo and Balasubramanian 2013).

Removal of heavy metals requires high operational and maintenance cost and the technologies available are expensive (Opeolu et al. 2010). The employed wastewater treatment methods include reverse osmosis, precipitation, ion exchange and adsorption (Ahalya et al. 2003). Ion exchange, membrane filtration and coagulation are generally used for treating chromium-laden wastewater (Fabbricino et al. 2013). Adsorption is an option which provides benefits such as a clearer effluent and possibility 
of heavy metal recovery at a low cost (Shankar et al. 2014).

Adsorbents commonly used for chromium adsorption include alginate (Navarro et al. 2006) and activated carbon (Mohan and Pittman 2006), imidazole functionalized solgel (Park and Tavlarides 2008 ), microorganisms like fungi, bacteria and algae, tobacco dust, plant biomass and also agricultural wastes such as rice bran, soybean, cottonseed hulls, coconut shell and chitin(Opeolu et al. 2010). For the adsorption of chromium, aquatic weeds (Elangovan et al. 2008; Yun et al. 2001), short-chain polyaniline synthesized on jute fiber (Kumar et al. 2008), grape stalks and yohimbe bark (Fiol et al. 2008), sugarcane bagasse (Garg et al. 2009) and the fungus Coriolus versicolor (Sanghi et al. 2009), among others, have been used. Trivalent chromium is said to be sorbed onto biosorbents by mechanisms like ion exchange, surface complexation or a combination of both depending on the biosorbent used and the available functional group (Han et al. 2006).

India is one of the top ten producers of aquaculture products in the world (Greenfacts 2010). The export of shrimps and crabs is usually done in a canned form for which meat is shelled and processed further. The unused shells sometimes are sold to poultry farms as feed but the quantity thus used is not comparable to tonnes of waste that is generated. Additionally, the disposal of this waste causes environmental problems. This waste in the form of chitin is a potential biosorbent of heavy metals. Chitin, obtained from crustacean shells is the second most abundant natural polysaccharide (Kumar 2000). Chitin contains 5-8\% of nitrogen in the form of aliphatic amino groups (Dutta et al. 2004). Chitosan is a polymer of glucosamine, found naturally in some fungal cell wall, produced chemically from the deacetylation of chitin. Chitin and chitosan are renewable, biodegradable, non-toxic polymers with very good adsorptive capacity (Dutta et al. 2004). Chitosan chelates five to six times greater amount of metals than chitin due to the free amino groups exposed during deacetylation. Adsorption capacity of chitosan varies with affinity for water, percent deacetylation and amino group content. Chitosan has been modified and its composites have been produced to improve the adsorptive capacity. Composites like chitosan-coated calcium silicate hydrate (Zhao et al. 2014), chitosan polystyrene blend (Acharyulu et al. 2014), chitosan graft acrylonitrile copolymer (Shankar et al. 2014) and poly(vinyl alcohol)/citric acid/chitosan beads (Zuo and Balasubramanian 2013) have produced good results. Chitin and chitosan are low-cost adsorbents and are commercially available at industrial grade for approximately \$ 4-6 and \$ 13 per kilogram, respectively (as per the correspondence with Axiogen Biotech, Pondicherry).

This paper presents a study on the comparative sorption efficiency for chromium by unmodified chitin and chitosan.

\section{Materials and methodology}

Chitin was procured from Aquatech Biosolutions, Nellore, India, and chitosan was prepared from it following Qurashi et al. (1992). The chitin was deacetylated by soaking it in $50 \% \mathrm{NaOH}$ for $3 \mathrm{~h}$ at $110{ }^{\circ} \mathrm{C}$ in a hot air oven (Tempo Instruments). The resulting solution was decanted and the chitosan was washed several times with distilled water until the $\mathrm{pH}$ lowered to neutral. Chitosan was sun dried for 3 days. Both chitin and chitosan were ground until they could pass through \#4 sieve $(4.75 \mathrm{~mm})$.

Degree of deacetylation (DD)

$\mathrm{N}$-deacetylation of chitosan was determined by baseline method following Qurashi et al. (1992) and the IR spectrum obtained using Perkin Elmer Spectrum RX 1 FTIR spectrophotometer. The spectrum was traced on a graph and the area covered by the peaks was calculated and interpreted using the following Eq. (1):

$\% \mathrm{~N}-$ deacetylation $=\left(1-\frac{A_{1655}}{A_{3450}} \times \frac{1}{1.33}\right) \times 100$,

where $A$ is the logarithmic ratio of the absorbance and transmittance at a given wavenumber.

This is based on the relationship between the absorbance value at $1,655 \mathrm{~cm}^{-1}$, which corresponds to amide group and the hydroxyl group which is at $3,450 \mathrm{~cm}^{-1}$ (Monteiro and Airoldi 1999).

\section{Adsorption study}

A one thousand grams per liter stock solution of chromium was prepared using chromium sulfate (AR grade). Then solution of the desired concentration was prepared from the stock solution. $100 \mathrm{mg}$ of each adsorbent (chitin and chitosan) was added to $50 \mathrm{ml}$ of $50 \mathrm{mg} / \mathrm{L}$ chromium sulfate solution taken in $250 \mathrm{ml}$ Erlenmeyer flask. This was agitated at $150 \mathrm{rpm}$ for $4 \mathrm{~h}$ in a rotary shaker KS501 digital of KIKA Labortechnik. The volume in the flask was filtered using Whatman No.1 filter paper. The sample was stored in plastic bottles and refrigerated until analyzed. Chromium removal by the adsorbents was determined by measuring the concentration of chromium in the filtrate by atomic absorption spectroscopy using Perkin Elmer AAnalyst 800 atomic absorption spectrometer.

Time dependence studies

The optimum contact time for chromium removal by chitin and chitosan was determined by carrying out the adsorption experiment at $\mathrm{pH} 5$ which was tested to be the natural $\mathrm{pH}$ 
of the chromium solution. During the span of $4 \mathrm{~h}$, from $50 \mathrm{ml}$ test solution, samples were drawn at 4-min intervals and analyzed for the metal concentration. The time profile of the metal adsorption was sketched.

\section{Effect of $\mathrm{pH}$}

To study the effect of $\mathrm{pH}$ the experiment was carried out at the $\mathrm{pH}$ in the range $2-5$. The initial $\mathrm{pH}$ of the test solution was adjusted to the desired $\mathrm{pH}$ using either $0.5 \mathrm{M} \mathrm{H}_{2} \mathrm{SO}_{4}$ or $1 \mathrm{M} \mathrm{NaOH}$, as required. $\mathrm{pH}$ was not monitored during the course of the experiment. $100 \mathrm{mg}$ of adsorbent was added to the test solution and the solution was agitated at $150 \mathrm{rpm}$. The experiment time was determined from the time dependence study.

\section{Adsorption isotherm}

Relationship between adsorption capacity of chitin and chitosan and metals was established using the Langmuir (2) and Freundlich (3) adsorption equations. These equations can be applied for monomolecular adsorption of a single metal from a liquid phase to a solid (Minamisawa et al. 2004).

Langmuir adsorption equation:

$q_{\mathrm{e}}=\frac{q_{\max } b C_{\mathrm{e}}}{1+b C_{\mathrm{e}}}$

Freundlich adsorption equation:

$q_{\mathrm{e}}=K_{\mathrm{f}} C_{\mathrm{e}}^{1 / n}$,

where $q_{\max }$ is the maximum metal uptake $(\mathrm{mg} / \mathrm{g}), b$ is the Langmuir equilibrium constant $(1 / \mathrm{mg}), K_{\mathrm{f}}$ is the adsorption capacity at unit concentration $(1 / \mathrm{mg}), 1 / n$ is the strength of adsorption and $C_{\mathrm{e}}$ is the final concentration of the metal in the solution.

\section{Results and discussion}

The FTIR (Perkin-Elmer) spectrum indicated that the chitosan was deacetylated to $63 \%$ proving transformation of chitin into chitosan as chitin with more than $50 \%$ DD is referred to as chitosan (Bratskaya et al. 2004). The degree of deacetylation was determined to find out the extent to which the acetyl groups have been removed. Deacetylation makes the chitosan a better adsorbent as it has more sites onto which adsorption can take place. The results have removal of more than half of the acetyl groups of chitin. Huang et al. (2000) reported DD ranging between 48 and $86 \%$ for chitosan which was prepared with varying concentration of $\mathrm{NaOH}$ and reaction time. Chitin is reported to have acetamido group at C-2 position. Chitosan is reported
Table 1 Properties of chitin and chitosan

\begin{tabular}{|c|c|c|c|}
\hline $\begin{array}{l}\text { S. } \\
\text { no. }\end{array}$ & Properties & Chitin & Chitosan \\
\hline 1. & $\begin{array}{l}\text { Functional } \\
\text { group and } \\
\text { their position }\end{array}$ & Acetamido at C-2 & $\begin{array}{l}\text { Amino group at C-2 } \\
\text { Hydroxyl group at C-3 } \\
\text { and C- } 6\end{array}$ \\
\hline 2. & Polymer & $\begin{array}{l}\beta(1 \rightarrow 4) \text {-linked } \\
2 \text {-acetamido-2- } \\
\text { deoxy- } \beta \text {-D-glucose } \\
(\mathrm{N} \text { - } \\
\text { acetylglucosamine })\end{array}$ & $\begin{array}{l}\alpha(1 \rightarrow 4) \text {-linked } \\
\text { 2-amino-2-deoxy- } \beta \text { - } \\
\text { D-glucopyranose }\end{array}$ \\
\hline 3. & Solubility & \multicolumn{2}{|c|}{$\begin{array}{l}\text { Insoluble in water and soluble in acidic } \\
\text { solutions (Kumirska et al. 2011) }\end{array}$} \\
\hline
\end{tabular}

Table 2 Equilibrium achieved and chromium adsorption efficiency from the metal solution at various $\mathrm{pH}$ using chitin and chitosan

\begin{tabular}{|c|c|c|c|c|c|}
\hline \multirow[t]{2}{*}{ Experiment } & \multirow[t]{2}{*}{$\mathrm{pH}$} & \multicolumn{2}{|c|}{$\begin{array}{l}\text { Chromium adsorption } \\
\text { efficiency }(\%)\end{array}$} & \multicolumn{2}{|c|}{$\begin{array}{l}\text { Equilibrium } \\
\text { (min) }\end{array}$} \\
\hline & & Chitin & Chitosan & Chitin & Chitosan \\
\hline 1 & 2 & 49.92 & 50 & 20 & 28 \\
\hline 2 & 3 & 49.98 & 49.99 & 20 & 20 \\
\hline 3 & 4 & 49.9 & 49.88 & 16 & 20 \\
\hline 4 & 5 & 49.94 & 49.84 & 20 & 20 \\
\hline
\end{tabular}

to contain three types of reactive functional groups that are the amino group at the C-2 position and primary and secondary hydroxyl groups at the C-3 and C- 6 positions, respectively. Some of the properties of chitin and chitosan are listed in Table 1.

Based on the time dependence study, a contact time of $40 \mathrm{~min}$ was fixed for chitin and chitosan. This included 10 min more than the resulting optimum time. The two adsorbents reached equilibrium at different contact times according to the $\mathrm{pH}$ of the solution. Equilibrium attained by both adsorbents ranged between 16 and $28 \mathrm{~min}$. Table 2 shows the amount of chromium adsorbed by chitin and chitosan varied accordingly.

Chitin exhibited highest chromium removal of $49.98 \%$ at $\mathrm{pH}$ 3. Chitosan, on the other hand, adsorbed chromium to the most of its capacity at $\mathrm{pH} 2$. This was achieved in $28 \mathrm{~min}$, whereas at $\mathrm{pH} 3$ in $20 \mathrm{~min} 49.99 \%$ of chromium is removed which is only $0.2 \mathrm{mg}$ less than that at $\mathrm{pH} 2$. This shows that the adsorption at $\mathrm{pH} 3$ was better, considering the lower contact time taken. This is similar to the observation of Dantas et al. (2001). The highest adsorption in their experiment was attained at $\mathrm{pH}$ 2.5-3.5. Baran et al. (2007) have also reported $\mathrm{pH} 3$ to be the optimum $\mathrm{pH}$ for both chitin and chitosan although the optimum contact time was higher. The amine groups of chitosan have $\mathrm{p} K_{\mathrm{a}}$ value of about 6.3; at $\mathrm{pH}$ lower than this the chitosan is protonated and cationic due to which the adsorption capacity 


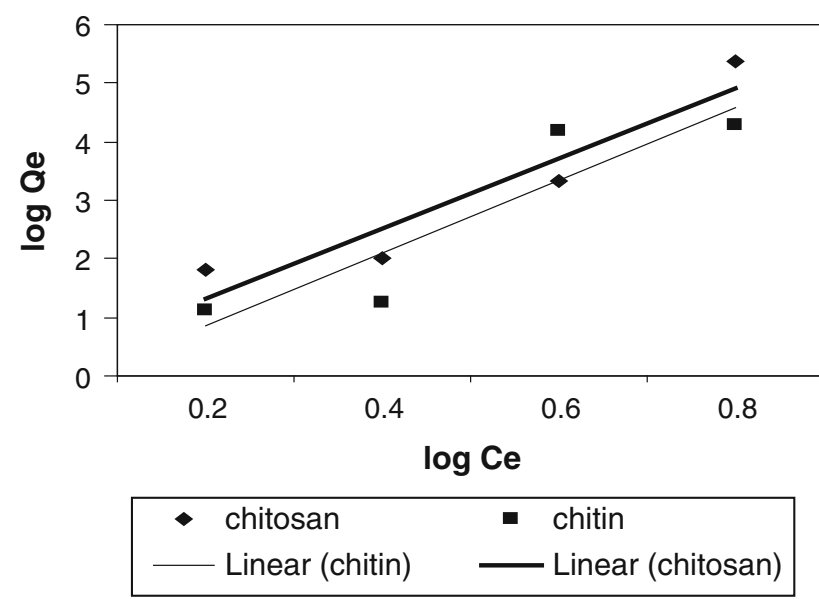

Fig. 1 Freundlich isotherm for chromium adsorption onto chitin and chitosan

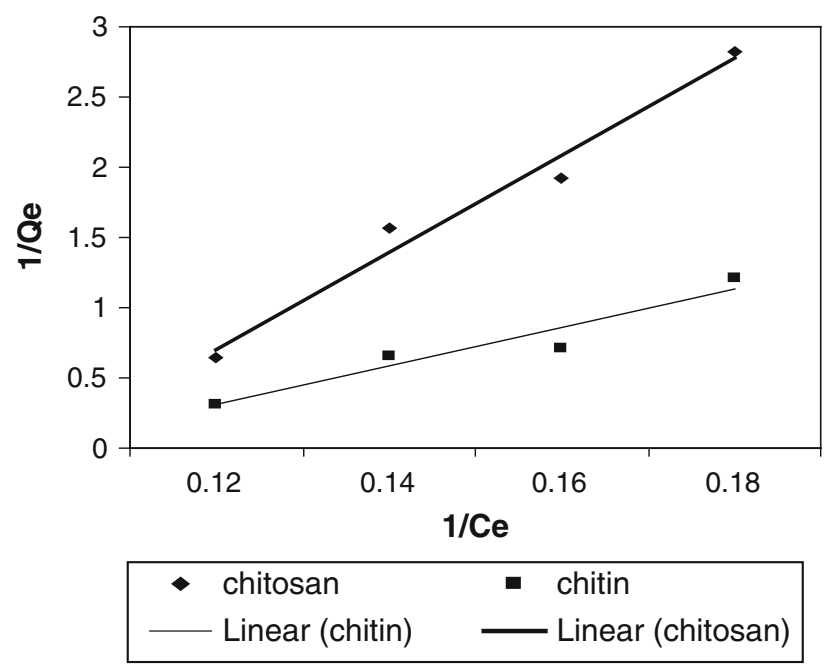

Fig. 2 Langmuir isotherm for chromium adsorption onto chitin and chitosan

increases (Shetty 2006). The protonation decreases as the $\mathrm{pH}$ increases and consequently the adsorption also decreases. Amine groups are mainly involved in binding with chromium. The chromium ions bind with the negatively charged surface of chitosan by electrostatic interaction (Nomanbhay and Palanisamy 2005).

Table 2 shows the $\mathrm{pH}$ dependent adsorption trend for chromium. The adsorption increased from $\mathrm{pH} 2$ to $\mathrm{pH} 3$ and then decreased as the $\mathrm{pH}$ increased. There is a noticeable decrease in sorption because chromium begins to precipitate as it comes into contact with adsorbent at a $\mathrm{pH}$ higher than 4.5 due to the alkaline nature of the adsorbent surface. Udaybhaskar et al. (1990) have also reported a decrease in chromium removal as the $\mathrm{pH}$ increased from 3 to 5 . The experiment also shows that the process is highly $\mathrm{pH}$ dependent. Thavamani and Rajkumar
Table 3 Freundlich and Langmuir isotherm constants for the sorption of chromium onto chitin and chitosan

\begin{tabular}{|c|c|c|c|c|c|c|c|}
\hline \multirow[t]{3}{*}{ S. No. } & \multirow[t]{3}{*}{ Adsorbent } & \multicolumn{6}{|c|}{ Isotherm } \\
\hline & & \multicolumn{3}{|c|}{ Freundlich } & \multicolumn{3}{|c|}{ Langmuir } \\
\hline & & $K_{\mathrm{f}}$ & $1 / n$ & $R^{2}$ & $q_{\max }$ & $b$ & $R^{2}$ \\
\hline 1 & Chitosan & 1.13 & 1.2 & 0.894 & 51.12 & 1.449 & 0.973 \\
\hline 2 & Chitin & 1.01 & 0.812 & 0.831 & 7.738 & 3.64 & 0.915 \\
\hline
\end{tabular}

(2013) confirm the same stating that the availability of adsorption sites and solubility of metal ions in the solution.

Freundlich and Langmuir isotherms for chromium sorption from the metal solution by chitin and chitosan are shown in Figs. 1 and 2, where Qe and Ce are the amounts of chromium adsorbed at equilibrium and equilibrium concentration of chromium, respectively.

Langmuir and Freundlich isotherms indicated good sorption results. The Langmuir isotherm is based on monolayer saturation, whereas Freundlich isotherm gives the adsorption on a heterogeneous surface (Nomanbhay and Palanisamy 2005). Regression coefficients for chromium sorption using chitosan and chitin were 0.973 and 0.915 for Langmuir isotherm and 0.894 and 0.831 for Freundlich isotherm. This indicated that the Langmuir relationship gives a better fit to the experimental data than Freundlich, indicating the monolayer interaction of chromium on the adsorbents. The same conclusion was drawn by Dantas et al. (2001). Udaybhaskar et al. (1990) reported a regression coefficient for Langmuir isotherm of 0.9995 and of 0.9648 for Freundlich isotherm in their experiment on chromium interaction with chitosan. The constants of Langmuir and Freundlich isotherms for chromium adsorption on chitin and chitosan are summarized in Table 3. The results in Table 3 also show that chitosan is a better adsorbent than chitin. This result was reported by Ngah and Musa (1998). The difference in efficiency of chitin and chitosan is not remarkable in this case but it will increase with chitosan of higher degree of deacetylation. This was confirmed in an experiment conducted by Liu et al. in 2013. They stated that at degree of deacetylation lower than $85 \%$ chitosan in barely soluble in water. Chitosan with higher DDA has more number of free amine groups available for adsorption (Mnatsakanyan et al. 2013; Guibal et al. 2014).

\section{Conclusion}

The results indicate that both the adsorbents have shown good adsorption capacity but chitosan is more efficient (at lower $\mathrm{pH}$ ). The experiment is highly $\mathrm{pH}$ dependent which is characteristic of adsorption process. Use of chitin and chitosan for the removal of heavy metals will take care of 
two issues: the removal of many toxic heavy metals from industries and the utilization of seafood processing waste. Nevertheless, pollution is transferred from the wastewater to a solid, at higher concentration levels. The non-toxic, biodegradable, biocompatible properties of both the adsorbents make them competent for the heavy metal removal from wastewater.

Open Access This article is distributed under the terms of the Creative Commons Attribution License which permits any use, distribution, and reproduction in any medium, provided the original author(s) and the source are credited.

\section{References}

Acharyulu SR, Prakash N, Sudha PN (2014) Chitosan blended polystyrene synthesis and its use to remove the toxic effects of chromium and copper from industrial wastewater. Der Pharma Chemica 6(2):177-186

Ahalya N, Ramachandra TV, Kanamadi RD (2003) Biosorption of heavy metals. Res J Chem Environ 7(4):71-79. http://wgbis.ces. iisc.ernet.in/energy/water/paper/biosorption/Biosorption.pdf Accessed 27 Jun 2014

Banerjee D, Kuila P, Ganguly A, Ray L (2010) Market basket survey for chromium, copper, lead and cadmium in some vegetables from different shopping malls in Kolkata, India. Electronic J Environ Agr Food Chem 9(7):1190-1195. http:// cabdirect.org/abstracts/20103366573.html;jsessionid=79AA7B 372EDA954C70FCBCE4956A1021 Accessed 27 Jun 2014

Baran A, Bıçak E, Baysal ŞH, Önal S (2007) Comparative studies on the adsorption of $\mathrm{Cr}(\mathrm{VI})$ ions on to various sorbents. Bioresour Technol 98(3):661-665

Bratskaya S, Schwarz S, Chervonetsky D (2004) Comparative study of humic acids flocculation with chitosan hydrochloride and chitosan glutamate. Water Res 38(12):2955-2961

Dantas TNC, Neto AAD, Moura MCPA, Neto ELB, Telemaco EP (2001) Chromium adsorption by chitosan impregnated with microemulsion. Langmuir 17(14):4256-4260

Dutta PK, Dutta J, Tripathi VS (2004) Chitin and chitosan: chemistry, properties and applications. J Sci Ind Res 63:20-31. http://nopr. niscair.res.in/bitstream/123456789/5397/1/JSIR\%2063(1)\% 2020-31.pdf?pagewanted=all Accessed 27 Jun 2014

Elangovan R, Philip L, Chandraraj K (2008) Biosorption of chromium species by aquatic weeds: kinetics and mechanism studies. J Hazard Mater 152(1):100-112

Fabbricino M, Naviglio B, Tortora G, d'Antonio L (2013) An environmental friendly cycle for $\mathrm{Cr}$ (III) removal and recovery from tannery wastewater. J Environ Manag 117:1-6

Fiol N, Escudero C, Villaescusa I (2008) Chromium sorption and $\mathrm{Cr}(\mathrm{VI})$ reduction to $\mathrm{Cr}(\mathrm{III})$ by grape stalks and yohimbe bark. Bioresour Technol 99(11):5030-5036

Garg UK, Kaur MP, Sud D, Garg VK (2009) Removal of hexavalent chromium from aqueous solution by adsorption on treated sugarcane bagasse using response surface methodological approach. Desalination 249(2):475-479

Greenfacts (2010) Table 4: top ten aquaculture producers of food fish supply: quantity and growth. http://www.greenfacts.org/en/ fisheries/figtableboxes/4.htm Accessed 12 Aug 2010

Guibal E, Vincent T, Navarro R (2014) Metal ion biosorption on chitosan for the synthesis of advanced materials. J Mater Sci 49:5505-5518
Han X, Wong YS, Tam NFY (2006) Surface complexation mechanism and modeling in $\mathrm{Cr}(\mathrm{III})$ biosorption by a microalgal isolate, Chlorella miniata. J Colloid Interf Sci 303(2):365-371

Huang C, Chen S, Pan JR (2000) Optimal condition for modification of chitosan: a biopolymer for coagulation of colloidal particles. Water Res 34(3):1057-1062

Igwe JC, Abia AA (2006) A bioseparation process for removing heavy metals from wastewater using biosorbents. Afr J Biotechnol 5(12):1167-1179

Kumar MNVR (2000) A review of chitin and chitosan applications. React Funct Polym 46(1):1-27

Kumar PA, Chakraborty S, Ray M (2008) Removal and recovery of chromium from wastewater using short chain polyaniline synthesized on jute fiber. Chem Eng J 141(1-3):130-140

Kumirska J, Weinhold MX, Czerwicka M, Kaczyński Z, Bychowska A, Brzozowski K, Thöming J, Strepnowski P (2011) Influence of the Chemical Structure and Physicochemical Properties of Chitinand Chitosan-Based Materials on Their Biomedical Activity. In: Laskovski A (ed) Biomedical Engineering, Trends in Materials Science. ISBN: 978-953-307-513-6, InTech, pp 25-64. http:// www.intechopen.com/books/biomedical-engineering-trends-inmaterialsscience/influence-of-the-chemical-structure-and-physic ochemical-properties-of-chitin-and-chitosan-basedmate Accessed 14 Jan 2013

Liu Y, Liu Y, Hu X, Guo Y (2013) Adsorption of Cr(VI) by modified chitosan from heavy-metal polluted water of Xiangiiang River, China. Trans Nonferrous Met Soc China 23:3095-3103

Minamisawa M, Minamisawa H, Yoshida S, Takai N (2004) Adsorption behavior of heavy metals on biomaterials. J Agric Food Chem 52(18):5606-5611

Mnatsakanyan M, Thevarajah JJ, Roi RS, Lauto A, Gaborieau M, Castignolles P (2013) Separation of chitosan by degree of acetylation using simple free solution capillary electrophoresis. Anal Bioanal Chem 405:6873-6877

Mohan D, Pittman C Jr (2006) Activated carbons and low cost adsorbents for remediation of tri- and hexavalent chromium from water. J Hazard Mater 137(2):762-811

Monteiro OAC Jr, Airoldi C (1999) Some thermodynamic data on copper-chitin and copper-chitosan biopolymer interactions. J Colloid Interf Sci 212(2):212-219

Mukherjee K, Saha R, Ghosh A, Saha B (2013) Chromium removal technologies. Res Chem Intermed 39:2267-2286

Navarro RR, Furukawa M, Matsumura M (2006) Hybrid properties of Alginate-PEI adsorbent for Chromium (VI) removal from aqueous solutions. Sep Sci Technol 41(16):3619-3637

Ngah WSW, Musa A (1998) Adsorption of humic acid onto chitin and chitosan. J Appl Polym Sci 69:2305-2310

Nomanbhay SM, Palanisamy K (2005) Removal of heavy metal from industrial wastewater using chitosan coated oil palm shell charcoal. Electron J Biotechnol 8(1):43-53. http://www. ejbiotechnology.info/index.php/ejbiotechnology/article/view/ v8n1-7/430 Accessed 27 Jun 2014

Opeolu BO, Bamgbose O, Arowolo TA, Adetunji MT (2010) Utilization of biomaterials as adsorbents for heavymetals' removal from aqueous matrices. Sci Res Essays 5(14): 1780-1787. http://www.academicjournals.org/article/article13 80633846_Opeolu\%20et\%20al.pdf Accessed 27 Jun 2014

Park HJ, Tavlarides LL (2008) Adsorption of Chromium (VI) from aqueous solutions using an Imidazole functionalized adsorbent. Ind Eng Chem Res 47(10):3401-3409

Qurashi MT, Blair HS, Allen SJ (1992) Studies on modified chitosan membranes. I. Preparation and characterization. J Appl Polym Sci 46(2):255-261

Sanghi R, Sankararamakrishnan N, Dave BC (2009) Fungal bioremediation of chromates: conformational changes of biomass 
during sequestration, binding and reduction of hexavalent chromium ions. J Hazard Mater 169(1-3):1074-1080

Shankar P, Gomathi T, Vijayalakshmi K, Sudha PN (2014) Comparative studies on the removal of heavy metals ions onto crosslinked chitosan-g-acrylonitrile copolymer. Int J Biol Macromol 67:180-188

Shetty AR (2006) Metal anion removal from wastewater using chitosan in a polymer enhanced diafiltration system. Dissertation, Worcester Polytechnic Institute

Shrivastava R, Upreti RK, Seth PK, Chaturvedi UC (2002) Effects of chromium on the immune system. FEMS Immunol Med Microbiol 34(1):1-7

Thavamani SS, Rajkumar R (2013) Removal of Cr(VI), Cu(II), Pb(II) and $\mathrm{Ni}(\mathrm{II})$ from Aqueous Solutions by Adsorption on Alumina. Res J Chem Sci 3(8):44-48
Udaybhaskar P, Iyengar L, Rao AVSP (1990) Hexavalent chromium interaction with chitosan. J Appl Polym Sci 39(3):739-747

Yun YS, Park D, Park JM, Volesky B (2001) Biosorption of trivalent chromium on the brown seaweed biomass. Environ Sci Technol 35(21):4353-4358

Zhao J, Zhu Y, Wu J, Zheng J, Zhao X, Lu B, Chen F (2014) Chitosan-coated mesoporous microspheres of calcium silicate hydrate: environmentally friendly synthesis and application as a highly efficient adsorbent for heavy metal ions. J Colloid Interf Sci 418:208-215

Zuo XJ, Balasubramanian R (2013) Evaluation of a novel chitosan polymer-based adsorbent for the removal of chromium (III) in aqueous solutions. Carbohydr Polym 92:2181-2186 